Editorial

\title{
The scientific journal in the post-truth era
}

Robert J Casson FRANZCO DPhil ${ }^{1}$ and Salmaan Al-Qureshi FRANZCO²

1. South Australian Institute of Ophthalmology, University of Adelaide, Adelaide, South Australia, Australia

2. Centre for Eye Research Australia, Melbourne, Victoria, Australia

Correspondence: Prof Robert Casson, South Australian Institute of Ophthalmology, University of Adelaide, Adelaide, South Australia, Australia

Robert.casson@adelaide.edu.au

Funding sources / Financial disclosure: None

Conflict of interest: None

This is the author manuscript accepted for publication and has undergone full peer review but has not been through the copyediting, typesetting, pagination and proofreading process, which may lead to differences between this version and the Version of Record. Please cite this article as doi: 10.1111/ceo.13733

This article is protected by copyright. All rights reserved. 
Last year marked the $50^{\text {th }}$ anniversary of the Apollo 11 Moon landing. After a 3-day trip and a glide path descent using rocket retrofire, Neil Armstrong engaged the Eagle's semi-manual override to avoid a boulder-strewn crater and safely touch down on smooth terrain in the Sea of Tranquility with 25 seconds of fuel remaining in the tank. Buzz Aldrin immediately announced, "Contact light", the first words spoken on the Moon. About $6 \frac{1}{2}$ hours later, Neil planted his left foot on the Moon and made his unrehearsed famous remark comparing a human stride to human progress. They did so using only Newtons Laws of motion set forth in the Principia Mathmatica published in 1687. On Christmas Eve in the preceding year, whilst in lunar orbit, Bill Anders in Apollo 8 captured on $70 \mathrm{~mm}$ colour Kodak the beautiful photo of Earthrise, commenting at the time, "There's the Earth coming up. Wow, that's pretty." It sure is Bill. Thanks for that one. Oddly, there is a growing collective with different ideas about Earthrise. This year there are reports that another group of intrepid individuals will embark on a $21^{\text {st }}$ Century voyage of discovery. These modern-day explorers are setting forth to find the Ice Wall. That's right, the Ice Wall: the 150-foot high wall of ice that surrounds the flat Earth and holds the oceans in. ${ }^{1}$ In November 2019 in Dallas, the Flat-Earth society held its third international conference, just a few months after the $50^{\text {th }}$ anniversary of Apollo 11. What is astonishing is that evidence of a spherical earth is literally in front of our eyes. A crescent moon shadow visible in the night's sky is a two-dimensional representation of a three dimensional spherical object. A flat earth would cast a liner shadow on the moon. Deductive reasoning it seems is out of fashion. The bizarre resurgence of flat earthers coincides with an alarming rise in the "antivaccination movement". In 2016, it was estimated that there were around 45,000 children in Texas who were exempted from state vaccination laws for "reasons of conscience". In some regions the unvaccinated rate is approaching $5 \%$, dangerously close to the $95 \%$ required for herd immunity. ${ }^{2}$ Concurrently, we have a President of the United States who describes climate change as both "serious" and "a hoax". However, in a 2018 interview with the Associated Press he reassured us from the Oval 
Office by commenting, "I have a natural instinct for science, ". 3 This was echoed by Australia's newest senator J im Molan who relies on things other than evidence (animal spirit guide?) on climate change.

The reasons for this growing anti-science movement are unclear but throughout the political spectrum. In 2016, the Oxford Dictionaries Word of the Year was post-truth, where it is defined as "relating to or denoting circumstances in which objective facts are less influential in shaping public opinion than appeals to emotion and personal belief". We believe that an appropriate response to this groundswell is captured by the fictional astronaut Mark Watney, in The Martian, "I'm left with only one option: I'm going to have to science the shit out of this. "We particularly like Watney's use of science as a verb, because that is what science is: a method of critical thinking that constantly self corrects by testing and refuting hypotheses.

Although it may play a minor role, the role of written peer reviewed scientific communication is essential in the practice of science. Curating the best science that it receives and then publishing it is a foundational activity of the scholarly professional group, which is what College holds itself to be. Without such endeavours it becomes a trade union. To that end this editorial board has published the best papers it has received out of the 19,000 manuscripts submitted over the past decade.

Clinical and Experimental Ophthalmology is now the highest ranked medical journal published in this region. Uniquely its North American and European readership dwarfs its local readers. Over the last decade the editorial board has sought to dramatically increase its scientific rigour and standard. A process begun prior to our tenure. A brief example illustrates this: 17 manuscripts submitted to this journal in which either of us have been authors, have been rejected by our own editorial board. So when your medial colleagues opine that ophthalmologists are no more than Ferrari driving dilatants rather than serious scholars, you can give the example of the journal, and remind them that there is no reason that one cannot be both. 
The journal now moves into a future of artificial intelligence on the horizon, with its first female editor, and perhaps its last human one. We wish J ustine Smith the very best and leave her with the sentiment that has continually inspired both of us "non futuis ascendit".

\section{REFERENCES}

1. Flat Earth Society. The Ice Wall [Online]. Available:

https://wiki.tfes.org/The_Ice_Wall [Accessed 6th Feb 2020].

2. Hotez, P. J. 2016. Texas and Its Measles Epidemics. PLoS Med, 13, e1002153.

3. Associated Press. Oct 17, 2018. Available:

https://apnews.com/a28cc17d27524050b37f4d91e087955e [Accessed 6th Feb 2020 ]. 


\section{University Library}

\section{- M M I E R R A A gateway to Melbourne's research publications}

Minerva Access is the Institutional Repository of The University of Melbourne

Author/s:

Casson, RJ;Al-Qureshi, S

Title:

The scientific journal in the post-truth era

Date:

2020-03-01

Citation:

Casson, R. J. \& Al-Qureshi, S. (2020). The scientific journal in the post-truth era. CLINICAL AND EXPERIMENTAL OPHTHALMOLOGY, 48 (2), pp.153-154. https://doi.org/10.1111/ ceo.13733.

Persistent Link:

http://hdl.handle.net/11343/275493 